\title{
Orphan receptor GPR37L1 contributes to the sexual dimorphism of central cardiovascular control
}

James L. J. Coleman ${ }^{1,2,3}$, Margaret A. Mouat ${ }^{1,2,3}$, Jianxin Wu ${ }^{3,4}$, Nikola Jancovski, ${ }^{5,6}$, Jaspreet K. Bassi ${ }^{5}$, Andrea Y. Chan ${ }^{3}$, David T. Humphreys ${ }^{2,7}$, Nadine Mrad ${ }^{1}$, Ze-Yan Yu ${ }^{2,4}$, Tony Ngo ${ }^{1,2,3}$, Siiri lismaa ${ }^{2,3}$, Cristobal G. dos Remedios ${ }^{8}$, Michael P. Feneley ${ }^{2,4}$, Andrew M. Allen ${ }^{5,6}$, Robert M. Graham ${ }^{2,3}$ and Nicola J. Smith ${ }^{1,2,3^{*}}$

\begin{abstract}
Background: Over 100 mammalian G protein-coupled receptors are yet to be matched with endogenous ligands; these so-called orphans are prospective drug targets for the treatment of disease. GPR37L1 is one such orphan, abundant in the brain and detectable as mRNA in the heart and kidney. GPR37L1 ablation was reported to cause hypertension and left ventricular hypertrophy, and thus, we sought to further define the role of GPR37L1 in blood pressure homeostasis.
\end{abstract}

Methods: We investigated the cardiovascular effects of GPR37L1 using wild-type (GPR37L $1^{\text {wt } / \text { wt }}$ ) and null (GPR37L $1^{\mathrm{KO} / \mathrm{KO}}$ ) mice established on a C57BL/6J background, both under baseline conditions and during Angll infusion. We profiled GPR37L1 tissue expression, examining the endogenous receptor by immunoblotting and a $\beta$-galactosidase reporter mouse by immunohistochemistry.

Results: GPR37L1 protein was abundant in the brain but not detectable in the heart and kidney. We measured blood pressure in GPR37L $1^{\text {wt } / \mathrm{wt}}$ and GPR37L $1^{\mathrm{KO} / \mathrm{KO}}$ mice and found that deletion of GPR37L1 causes a female-specific increase in systolic, diastolic, and mean arterial pressures. When challenged with short-term Angll infusion, only male GPR37L1 $1^{\mathrm{KO} / \mathrm{KO}}$ mice developed exacerbated left ventricular hypertrophy and evidence of heart failure, while the female GPR37L $1^{\mathrm{KO} / K O}$ mice were protected from cardiac fibrosis.

Conclusions: Despite its absence in the heart and kidney, GPR37L1 regulates baseline blood pressure in female mice and is crucial for cardiovascular compensatory responses in males. The expression of GPR37L1 in the brain, yet absence from peripheral cardiovascular tissues, suggests this orphan receptor is a hitherto unknown contributor to central cardiovascular control.

Keywords: G protein-coupled receptors, Orphan, Hypertension, Left ventricular hypertrophy, Central nervous system, Heart failure, Mouse model of hypertension

\section{Background}

High blood pressure (BP) is responsible for $>45 \%$ of heart disease deaths worldwide and is the single biggest contributing risk factor to global disease burden [1]. The human cost of hypertension is partially explained by the disorder's multifactorial pathogenesis and is accordingly

\footnotetext{
* Correspondence: n.smith@victorchang.edu.au

'Molecular Pharmacology Laboratory, Division of Molecular Cardiology and Biophysics, Victor Chang Cardiac Research Institute, Darlinghurst, NSW 2010, Australia

${ }^{2}$ St Vincent's Clinical School, University of New South Wales, Sydney, Australia Full list of author information is available at the end of the article
}

difficult to treat [2]. Approximately $30 \%$ of patients receiving treatment for hypertension do not have their BP adequately controlled by current pharmacotherapy [3]. Clearly, a better understanding of the mechanisms governing $\mathrm{BP}$ is necessary to more effectively manage cardiovascular disease.

One such BP regulator may be the $\mathrm{G}$ protein-coupled receptor (GPCR) GPR37L1. This orphan receptor (orphan-without a known endogenous ligand) is predominantly expressed in the brain $[4,5]$ and contributes to cerebellar development and motor skills [6]. Gpr37l1 
also lies within eight quantitative trait loci linked to $\mathrm{BP}$ regulation in the rat [7]. Moreover, a previous study [8] reported that GPR37L1 knockout mice have left ventricular hypertrophy ( $\mathrm{LVH}$ ) and $\sim 60 \mathrm{mmHg}$ higher systolic BP than that of cardiac-specific, GPR37L1overexpressing transgenic mice. However, the mouse strain, sex, age, heart rate, and depth of anesthesia used for BP measurement were not indicated, and BP was not compared to appropriate wild-type controls. Here, we sought to definitively establish whether GPR37L1 regulates BP using GPR37L1 null mice that we generated and maintained on a pure C57BL/6J background $[9,10]$. We report that GPR37L1 is indeed involved in BP regulation but in a sexually dimorphic manner.

\section{Methods}

Mouse line generation and maintenance

Male and female C57BL/6J GPR37L $1^{\text {wt/wt }}$, GPR37L $1^{\text {flx/flx }}$, GPR37L1 ${ }^{\text {wt/KO }}$, GPR37L1 ${ }^{\mathrm{KO} / \mathrm{KO}}$, and GPR37L1 $1^{\text {lacZ/wt }}$ were generated using the European Conditional Mouse Mutagenesis Program (EUCOMM) method for conditional gene inactivation using Cre/loxP and Flp1/FRT gene trapping [9] described as GOI\#1 in a previous report [10]. Mice were group-housed in a temperature-controlled environment with a 12-h light-dark cycle (lights on at 0700). Standard chow and water were available ad libitum. All animal work was performed in accordance with the Australia Code for the Care and Use of Animals for Scientific Purposes, 8th Edition (2013), and was approved by the relevant Animal Ethics Committees (Garvan Institute for Medical Research/St Vincent's Hospital, project number AEC 13/30; University of Melbourne, project number 1212573). All animals were entered into the study in a randomized order.

\section{Quantitative PCR}

Tissue was homogenized in TRIzol $(15,596,026$, Thermo Scientific, USA) using a PRO200 homogenizer (Bio-Gen, USA), and RNA was extracted using manufacturer's protocol (Thermo Scientific). DNA contamination was removed from extracted RNA with TURBO DNAse kit treatment (AM1907, Invitrogen, USA) before cDNA synthesis was performed using SuperScript ${ }^{\oplus}$ III First-Strand Synthesis Supermix as per manufacturer's protocol (11752050, Invitrogen). cDNA was stored at $-20{ }^{\circ} \mathrm{C}$ until use. Quantitative PCR (qPCR) was performed on cDNA using TaqMan Gene Expression Master Mix (4369016, Applied Biosystems, USA) and TaqMan probes (Applied Biosystems). All qPCR was performed using a LightCycler 480 (Roche, Switzerland) (cycling conditions: preincubation at $95{ }^{\circ} \mathrm{C}$ for $10 \mathrm{~min}$; 55 amplification cycles of $95{ }^{\circ} \mathrm{C}$ for $10 \mathrm{~s}, 58^{\circ} \mathrm{C}$ for $30 \mathrm{~s}$, and $72{ }^{\circ} \mathrm{C}$ for $30 \mathrm{~s}$; final cooling at $50{ }^{\circ} \mathrm{C}$ for $10 \mathrm{~s}$ ). Probe
Mm00661872_m1 was used to detect GPR37L1 in mouse. The following probes were used to detect components of the fetal gene program: ANP (Mm01255747_g1), BNP (Mm01255770_g1), $\beta-M H C$ (Mm00600555_m1), and $\alpha-S k A\left(M m 00808218 \_g 1\right) . \Delta \mathrm{Ct}$ values were calculated in reference to HPRT (mouse, Mm03024075_m1) or when GPR37L1 transcript abundance was determined in EUCOMM mice; $\Delta \mathrm{Ct}$ values were calculated in reference to $\beta 2 \mathrm{M}$ (mouse, Mm00437762_m1). Relative mRNA abundance was determined using the $2^{-\Delta \Delta \mathrm{Ct}}$ method [11].

\section{Tissues for pilot assay of GPR37L1 transcription}

In reference to the experiment shown in Additional file 1: Figure S1, surplus tissue (left and right ventricles, left and right atria, aorta, kidney, lung, liver, and brain) from sham-operated wild-type C57BL/6J mice (12 weeks old, male), as harvested for a previous study [12], was used to generate cDNA to quantify GPR37L1 by qPCR.

\section{Tissue fixation for $\beta$-galactosidase imaging}

Tissue fixation was performed as adapted from a previous method [13]. At $\geq 12$ weeks of age, GPR37L1 $1^{\text {wt } / w t}$ and GPR37L $1^{\text {lacZ/wt }}$ mice of either sex were anesthetized with $5 \%$ isofluorane in oxygen (flow rate $1 \mathrm{~L} / \mathrm{min}$ ) delivered via nose cone. The thoracic cavity was opened, and the LV was punctured with a needle that was then used to perfuse the heart with phosphate-buffered saline (PBS) (1 min; flow rate $20 \mathrm{~mL} / \mathrm{min})$, achieving sacrifice by exsanguination. Immediately after, tissues were fixed by further 2 min perfusion with $4 \%$ paraformaldehyde (PFA) in PBS (flow rate $20 \mathrm{~mL} / \mathrm{min}$ ). Following fixation, the brain, heart, and kidney were collected and further fixed in $4 \%$ PFA/PBS for $48 \mathrm{~h}$ at room temperature (RT). After post-fixation, tissue was stored in sucrose cryoprotectant buffer $(5 \mathrm{mmol} / \mathrm{L}$ Trizma base, $77 \mathrm{mmol} / \mathrm{L} \mathrm{NaCl}$, $4 \mathrm{mmol} / \mathrm{L} \mathrm{Na} \mathrm{NPO}_{4}, 1.3 \mathrm{mmol} / \mathrm{L} \quad \mathrm{NaH}_{2} \mathrm{PO}_{4}, 20 \%$ w/v sucrose) at $4{ }^{\circ} \mathrm{C}$ for $\geq 48 \mathrm{~h}$. Fixed and cryoprotected tissue was embedded in Tissue Freezing Medium (TFM5, Triangle Biomedical, USA) and frozen. Frozen tissue was cut into $12 \mu \mathrm{m}$ sections using a CM1950 Cryostat (Leica Biosystems, Germany) and mounted on Superfrost Plus Slides (Thermofisher Scientific).

\section{$\beta$-galactosidase immunofluorescent staining}

The protocol was performed at RT unless otherwise specified. Slides containing mounted tissue sections from the above procedure were washed for $10 \mathrm{~min}$, three times, in immunobuffer [TPBS $(10 \mathrm{mmol} / \mathrm{L}$ Tris, $8 \mathrm{mmol} / \mathrm{L} \mathrm{Na} \mathrm{HPO}_{4}, 2.6 \mathrm{mmol} / \mathrm{L} \mathrm{NaH} \mathrm{PO}_{4}, 0.9 \% \mathrm{NaCl}$, $0.05 \%$ thimerosal) with $0.3 \%$ Triton X-100]. Non-specific antibody binding was blocked by incubating each section in immunobuffer containing $10 \% v / v$ normal donkey serum (NDS) (017-000-121, Jackson ImmunoResearch 
Laboratories, USA) for $30 \mathrm{~min}$, in a humidifying chamber. Primary antibodies [1:250 chicken anti- $\beta$-galactosidase (AB9361, Abcam, Cambridge, UK) for all tissue, 1:500 rabbit anti-GFAP (Z0334, Agilent Technologies, USA) for brain only] were diluted in immunobuffer with $10 \% v / v$ NDS and applied to each section for $16 \mathrm{~h}$, in a humidifying chamber at $4{ }^{\circ} \mathrm{C}$. Slides were then washed for $10 \mathrm{~min}$, three times, in TPBS. For the remainder of the protocol, slides were shielded from ambient light. Secondary antibodies [1:500 donkey anti-chicken Cy3 (703-165-155, Jackson ImmunoResearch Laboratories) for all tissue, 1: 500 donkey anti-rabbit Alexa Fluor 647 (711-605-152, Jackson ImmunoResearch) for brain only], DAPI (1:5000 4',6-diamidino-2-phenylindole dihydrochloride; D9542, Sigma Aldrich, USA) nuclear stain, and wheat germ agglutinin (WGA) membrane stain (for heart and kidney only, 1:500 Alexa Fluor 488 WGA conjugate; W11261, Invitrogen) were diluted in immunobuffer containing 10\% $v / v$ NDS and applied to each section for $1 \mathrm{~h}$, in a humidifying chamber. Slides were then washed for $10 \mathrm{~min}$ in TPBS. To reduce autofluorescence, each section was then treated with $0.1 \%$ w/v Sudan Black B (S2380, Sigma Aldrich) in $70 \% v / v$ ethanol for $1 \mathrm{~h}$, in a humidifying chamber. Excess dye was then removed by washing for $10 \mathrm{~min}$, three times, in TPBS. Slides were then dried for $16 \mathrm{~h}$ in a humidifying chamber before being sealed with glass coverslips mounted using 2.5\% w/v DABCO (1,4-diazabicyclo[2,2,2]-octane; D2522, Sigma Aldrich), 10\% w/v polyvinyl alcohol (P8136, Sigma Aldrich), 25\% $w / v$ glycerol (G5516,

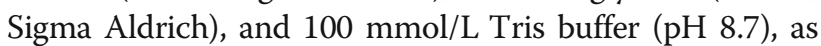
adapted from a previous method [14]. Slides were imaged on a LSM 7 Duo confocal microscope (Zeiss, Germany).

\section{Immunoblotting and densitometry}

Tissue homogenates and crude membranes were prepared as previously described $[15,16]$. SDS-PAGE and immunoblotting was performed as previously described [15]. GPR37L1 was detected using goat anti-GPR37L1 (C-12) antibody (1:1000; sc-164532, Santa Cruz Biotechnology, USA) that was previously confirmed to be GPR37L1specific using knockout tissue [15] and then rabbit anti-goat antibody (1:7500; $61-1620$, Invitrogen). $\beta$-galactosidase was detected using rabbit anti- $\beta$-galactosidase antibody (1:5000; A-11132; Invitrogen) and then donkey anti-rabbit antibody (1:15000, NA934, GE Healthcare, Australia). GAPDH was detected using rabbit anti-GAPDH antibody (1:10000; 14C10, Cell Signaling, USA) and then donkey anti-rabbit antibody (1:20000, NA934, GE Healthcare). SuperSignal ${ }^{\mathrm{mi}}$ West Pico (34080, Invitrogen) or Clarity ${ }^{\text {mi }}$ (1705060, Bio-Rad, USA) were used as chemiluminescent substrates. Densitometry was performed using ImageJ software (https://imagej.nih. gov/ij/) on non-saturated chemiluminescent exposures. Pixel density of background was measured and subtracted from subsequent measurements taken on the same image. Pixel density of GPR37L1 was measured in reference to the predominant, cleaved receptor species [15] and adjusted to equivalent protein abundance using each sample's own GAPDH pixel density score.

\section{Hemodynamic measurement and analysis}

At age 10-12 weeks, mice were anesthetized with 1-2\% isofluorane (Zoetis, USA) in oxygen (flow rate $0.5 \mathrm{~L} / \mathrm{min}$ ), delivered via nose cone regulated using a mechanical ventilator $(150 \quad$ strokes/min, $200 \mu \mathrm{l}$ stroke volume). Hemodynamics in the aorta and LV were recorded with a high-fidelity pressure transducer (Millar Instruments, USA) following its insertion into the right carotid artery as described previously $[17,18]$. Heart rate was maintained at approximately 500 beats per minute (bpm) by manual adjustment of the isofluorane concentration. Data were recorded and analyzed using AcqKnowledge software (version 3.9.0 for Windows, BIOPAC Systems, USA) by an observer blinded to genotype (and to treatment where applicable). Hemodynamics on osmotic mini pump animals were recorded using a Transonic Scisense (FTH1211B-001, USA) high-fidelity pressure transducer.

\section{Radiotelemetry blood pressure measurement}

At 12-14 weeks of age, mice were anesthetized with $2 \%$ isofluorane (Abbott Laboratories, USA), with the rate adjusted to provide a deep surgical plane. PA-C10 telemeters (Data Sciences International, USA) were implanted as previously described [19], with the pressuresensing catheter inserted into the left carotid artery. Analgesia was administered before and after surgery (carprofen, 0.5 mg/100 g, IP; Norbrook, UK). Hydration was maintained by administration of $0.5 \mathrm{~mL} 0.9 \% \mathrm{NaCl}$ (IP), given at the time of operation and again $24 \mathrm{~h}$ later. Approximately 2 weeks after telemeter implantation, blood pressure monitoring was performed twice daily in the home cage, between 09:00 and 12:00 (light phase) and between 21:00 and 24:00 (dark phase) for 9 days. The average of the 9 days of measurements in each phase was taken to give a single value per animal per phase. [N.B. radiotelemetry blood pressure monitoring was only performed during initial phenotyping experiments in Fig. 2c, d, as indicated].

\section{Angiotensin II infusion}

Osmotic mini pumps (product 1007D, Alzet) were filled with either vehicle $(0.15 \mathrm{~mol} / \mathrm{L} \mathrm{NaCl}, 1 \mathrm{mmol} / \mathrm{L}$ acetic acid) or AngII (A9525, Sigma Aldrich) at a concentration adjusted to allow $2 \mathrm{mg} / \mathrm{kg} /$ day release of AngII for 7 days. After filling, pumps were primed by incubation in $0.9 \% \mathrm{NaCl}$ for $16 \mathrm{~h}$ at $37^{\circ} \mathrm{C}$. Mice (10-12 weeks old) were anesthetized [inhaled 3-4\% isofluorane (Zoetis) in oxygen (flow rate $0.8-1.0 \mathrm{~L} / \mathrm{min}$ ) delivered by nose 
cone] and pumps implanted subcutaneously, as per the manufacturer's instructions. Following pump implantation, topical analgesia was administered in the form of bupivacaine (AstraZeneca, UK), and systemic analgesia was administered (SC) in the form of buprenorphine $(0.075 \mathrm{mg} / \mathrm{kg}$; Reckitt Benckiser, UK), before completion of surgery and recovery from anesthesia. Animals were allowed to recover from anesthesia on a heated pad, before being single-housed for the remainder of the study. [N.B. blood pressure following the 7 days of infusion was measured by anesthetized catheterization, as indicated].

\section{Morphometry}

Tissues were retrieved after sacrifice, briefly rinsed of blood in $0.9 \% \mathrm{NaCl}$, and then blotted dry. Tissue weights were measured immediately and expressed as a ratio of each animal's own tibia length, measured with caliMAX fine calipers (WIHA, Germany).

\section{Cardiomyocyte density}

Cardiomyocyte density was determined using an adaptation from a previous method [18]. Briefly, LV tissue was fixed in $4 \%$ PFA/PBS for $24 \mathrm{~h}$ at RT before postfixation, sectioning, and processing as described above for immunofluorescent staining and confocal microscopy. Cell membranes were visualized using 1:500 Alexa Fluor 488 WGA conjugate. Using ImageJ, an observer blinded to sex, genotype, and treatment counted cardiomyocytes from two representative areas of each LV and averaged them to give one value per animal. Cardiomyocyte counts were expressed as cells per square millimeter. Cardiomyocyte density was used instead of cardiomyocyte cross-sectional area as we found density to show less inter-observer variability (data not shown).

\section{Fibrosis staining}

LV tissue was fixed as described for cardiomyocyte density. Cytoplasm (red) and collagen (blue) were stained using Masson's trichrome stain as per the manufacturer's protocol (HT15, Sigma Aldrich). Coverslips were mounted onto slides using DEPEX mounting media (VWR International, USA). Sections were visualized with bright-field microscopy on a DM6000 power mosaic microscope (Leica Biosystems), and images were retained in RGB format. The degree of fibrosis was quantified using ImageJ by an observer blinded to sex, genotype, and treatment and expressed as a percentage of area occupied by blue-hued pixels relative to total cross-sectional tissue area, as adapted from previous methods [20].

\section{RNA sequencing analysis}

Human postmortem brain RNA sequencing data was obtained from the Genotype-Tissue Expression (GTEx) Consortium [21]. GTEx raw sequence counts were examined for differentially expressed genes using the edgeR statistical package [22], where samples were grouped by genders for each brain tissue sample.

\section{Statistical analysis}

All data are presented as mean \pm s.e.m. The number of independent observations $(n)$ in animal/human data represents a single animal/donor. Where multiple measurements were taken per animal, measurements were averaged to give a single observation $(n)$ per animal. Where two untreated genotypes (per sex) were analyzed, a two-tailed Student's $t$ test was used, or a one-tailed Mann-Whitney test, as indicated. Where $>2$ untreated genotypes (per sex) were analyzed, a one-way ANOVA was used with Dunnett's multiple comparisons tests, or Kruskal-Wallis test with Dunn's multiple comparisons test where ANOVA assumptions were violated. Where two genotypes (per sex), with and without treatment, were analyzed, a two-way ANOVA was used with Tukey's multiple comparisons test. For all tests, $p \leq 0.05$ was considered significant.

\section{Results}

GPR37L1 protein is abundant in the central nervous system but not detectable in the heart or kidney

Given the reported role of GPR37L1 in the cardiovascular system [8], we investigated GPR37L1 transcription by qPCR in several mouse tissues of interest, including the heart and kidney. We noted that GPR37L1 mRNA appeared at late cycle numbers in both tissues, suggesting very low relative expression (Additional file 1: Figure S1). To clarify the expression profile of GPR37L1, we used EUCOMM ES cells [9] to generate GPR37L $1^{\text {lacZ/wt }}$ mice (expressing one allele of $\beta$ galactosidase in place of GPR37L1) as we have described [10]. Consistent with previous reports of GPR37L1 localization [4-6, 23], $\beta$-galactosidase expression was most abundant in the brain, particularly in the cerebellar Bergmann glia (Fig. 1a, Additional file 1: Figure S2A). Astrocyte $\beta$-galactosidase co-localization was observed throughout the brain but was most evident in the hippocampus (Additional file 1: Figure S2B), while other regions such as the brain stem (Fig. 1a) and neocortex (Additional file 1: Figure S2C) contained GFAP-negative $\beta$-galactosidase-positive cells that were consistent with the reported expression of GPR37L1 in cells of oligodendrocyte lineage $[23,24]$. In several key cardiovascular centers of the CNS including the caudal and rostral ventrolateral medulla (CVLM, RVLM), the nucleus of the solitary tract (NTS), and the A5 nucleus, diffuse $\beta$-galactosidase 

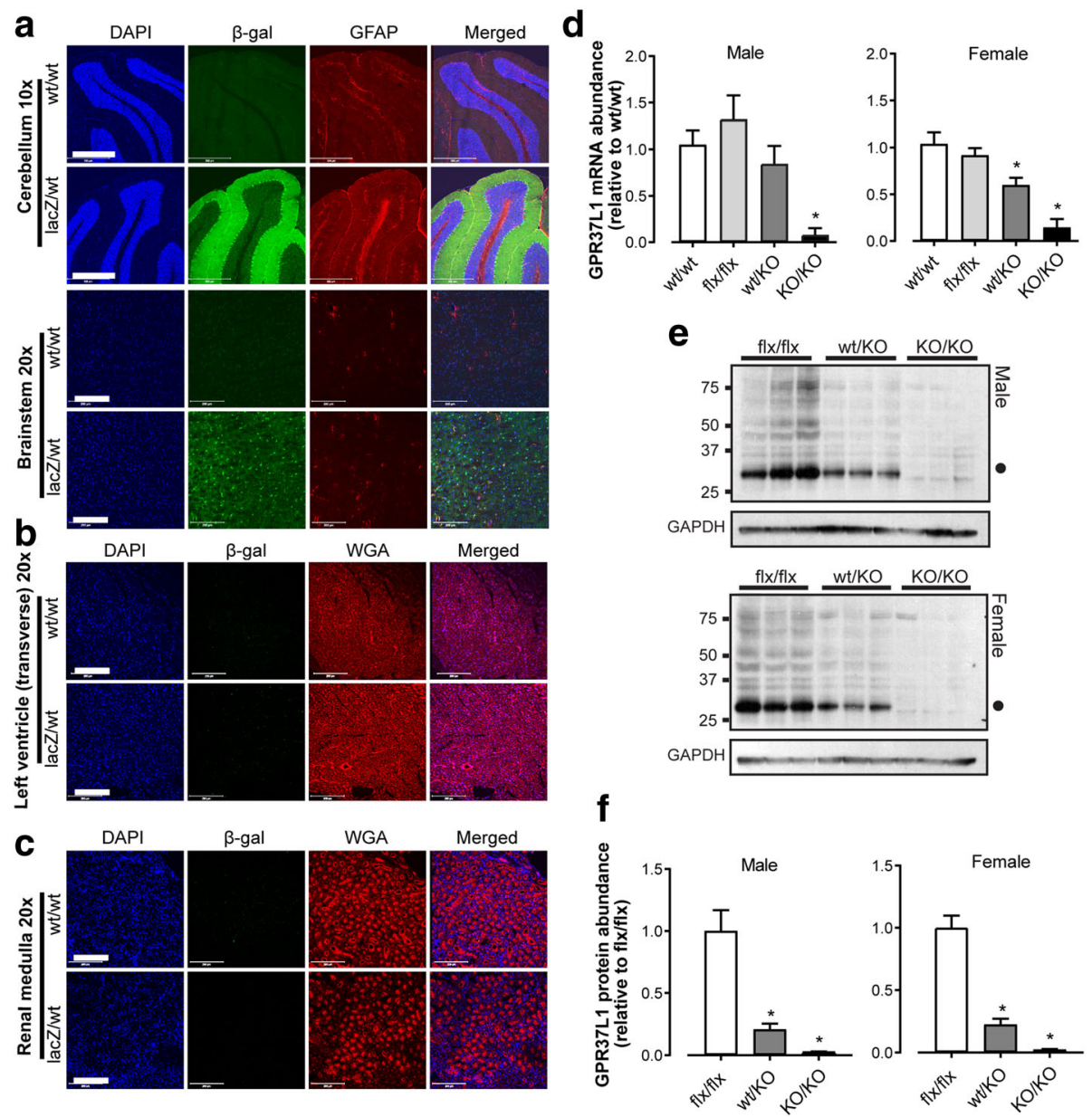

Fig. 1 GPR37L1 is abundant in the brain and ablated in EUCOMM-derived knockout mice. a-c Paraformaldehyde-fixed tissue from GPR37L 1acZ/wt and GPR37L1 ${ }^{\text {wt/wt }}$ mice (mixed-sex, $\geq 12$ weeks old) a Brain: nuclei (blue; DAPI); GPR37L1 $\beta$-galactosidase reporter (green; $\beta$-galactosidase antibody); astrocytes and the Bergmann glia [red, glial fibrillary acidic protein antibody (GFAP)]. Scale bars: $500 \mu \mathrm{m}(\times 10$ images) and $10 \mu \mathrm{m}(\times 20 \mathrm{images})$. b Heart and c kidney: nuclei (blue, DAPI); GPR37L1 $\beta$-galactosidase reporter (green; $\beta$-galactosidase antibody); cell membranes [red; wheat germ agglutinin (WGA)]. Images representative of $n=3$. Scale bar $=200 \mu \mathrm{m}$. $\mathbf{d}$ qPCR confirmed loss of cerebellar GPR37L1 mRNA in male and female GPR37L $1^{\mathrm{KO} / \mathrm{KO}}$ mice (10-12 weeks old, $n=6$, one-way ANOVA with Dunnett's multiple comparisons, $\left.{ }^{*} p \leq 0.05\right)$. e Immunoblot and $\mathbf{f}$ densitometry of GPR37L1 in cerebellar homogenates from male and female mice (genotypes as indicated, 10-12 weeks old, $n=3$, one-way ANOVA with Dunnett's multiple comparisons, $\left.{ }^{*} p \leq 0.05\right)$. Closed circle $\left(M_{\mathrm{r}} \sim 30 \mathrm{kD}\right)$ indicates predominant, cleaved GPR37L1 species [15]

staining was observed close to, but not within, tyrosine hydroxylase-positive catecholaminergic neurons (Additional file 1: Figure S3). In contrast, we were unable to detect GPR37L1 $\beta$-galactosidase reporter immunofluorescence in peripheral tissues. Although we measured low levels of GPR37L1 mRNA in the mouse heart (Additional file 1: Figure S1), we could not detect $\beta$ galactosidase by immunofluorescence (Fig. 1b, Additional file 1: Figure S4A) or Western blot (Additional file 1: Figure S4B), nor wild-type GPR37L1 using a validated [15] anti-GPR37L1 antibody (Additional file 1: Figure S4C-E). Similarly, we did not detect $\beta$-galactosidase in the renal medulla (Fig. 1c) or cortex (Additional file 1: Figure S5A), nor could it be detected in GPR37L1 $1^{\text {lacZ/wt }}$ kidney homogenates (Additional file 1: Figure S5B).
Endogenous GPR37L1 was not detected in GPR37L1 ${ }^{\text {wt/wt }}$ kidney (Additional file 1: Figure S5C). Because only GPR37L1 mRNA, but not protein, was found in the heart and kidney, we hypothesize that GPR37L1 exerts its cardiovascular effect via the CNS.

\section{GPR37L1 regulates blood pressure in female mice}

To investigate the role of GPR37L1 in the cardiovascular system, we further generated the GPR37L1 $1^{\mathrm{flx} / \mathrm{flx}}$ and GPR37L $1^{\mathrm{KO} / \mathrm{KO}}$ mice $[9,10]$. Receptor ablation in both genders was verified in the cerebellum (mRNA and protein, respectively; Fig. 1d-f), and in the LV (mRNA; Additional file 1: Figure S4F). GPR37L1 expression was unchanged in GPR37L1 ${ }^{\mathrm{fl} / \mathrm{flx}}$ as compared to GPR37L $1^{\text {wt/wt }}$ mice (generated from GPR37L $1^{\mathrm{wt} / K O}$ breeding pairs) 
(Fig. 1d, Additional file 1: Figure S6A and B). Thus, GPR37L $1^{\text {wt/wt }}$ mice were used as controls for the remainder of our studies.

Baseline cardiovascular measures were first assessed in anesthetized females by micromanometry (Fig. 2a) at a constant heart rate of $\sim 500 \mathrm{bpm}$ (Fig. 2b, Additional file 1: Table S1). Female GPR37L $1^{\mathrm{wt} / \mathrm{KO}}$ and GPR37L $1^{\mathrm{KO} / \mathrm{KO}}$ mice displayed significantly elevated aortic systolic pressure compared to controls (Fig. 2a, Additional file 1: Table S1). Furthermore, GPR37L1 ${ }^{\mathrm{KO} / \mathrm{KO}}$ females showed increased aortic diastolic, mean arterial, and pulse pressures (Fig. 2a, Additional file 1: Table S1). No genotype differences in LV systolic pressure, end-diastolic pressure, and $\mathrm{dP} / \mathrm{dT}$ max or $\mathrm{dP} / \mathrm{dT}$ min were observed. To confirm that this phenotype was preserved in conscious animals, radiotelemetry BP monitoring was performed on a separate cohort of conscious GPR37L $1^{\text {wt } / w t}$ and GPR37L $1^{\mathrm{KO} / \mathrm{KO}}$ females. Again, GPR37L $1^{\mathrm{KO} / \mathrm{KO}}$ females had elevated systolic and diastolic pressure, during both light and dark phases of the diurnal cycle, relative to GPR37L $1^{\text {wt/wt }}$ controls (Fig. 2c).
To investigate if GPR37L1 deletion is deleterious in the setting of hypertensive stress, female GPR37L $1^{\text {wt/wt }}$ and GPR37L1 $1^{\mathrm{KO} / \mathrm{KO}}$ mice were infused for 7 days with AngII (2 $\mathrm{mg} / \mathrm{kg} /$ day) or vehicle, before anesthetized hemodynamic measurement by pressure-transducing catheter and tissue collection. AngII infusion caused greater increases in systolic and mean arterial pressure in the GPR37L $1^{\mathrm{wt} / \mathrm{wt}}$ females (Table 1), presumably because GPR37L1 $1^{\mathrm{KO} / \mathrm{KO}}$ females have higher baseline systolic pressure (one-tailed Mann-Whitney test, $p \leq 0.05$ ), consistent with our previous, independent cohort (Fig. 2). However, BP after 7 days of AngII did not differ between genotypes (Table 1), and both developed equivalent gross, cellular, and molecular LVH (Fig. 3a, b, Additional file 1: Figure S7, Figure S8), without progression to overt heart failure (see relative lung and right ventricle weights; Fig. 3c, Table 1). Although GPR37L1 ${ }^{\mathrm{wt} / \mathrm{wt}}$ females developed cardiac fibrosis in response to AngII treatment, this was not observed in GPR37L1 ${ }^{\mathrm{KO} / \mathrm{KO}}$ females (Fig. 4).
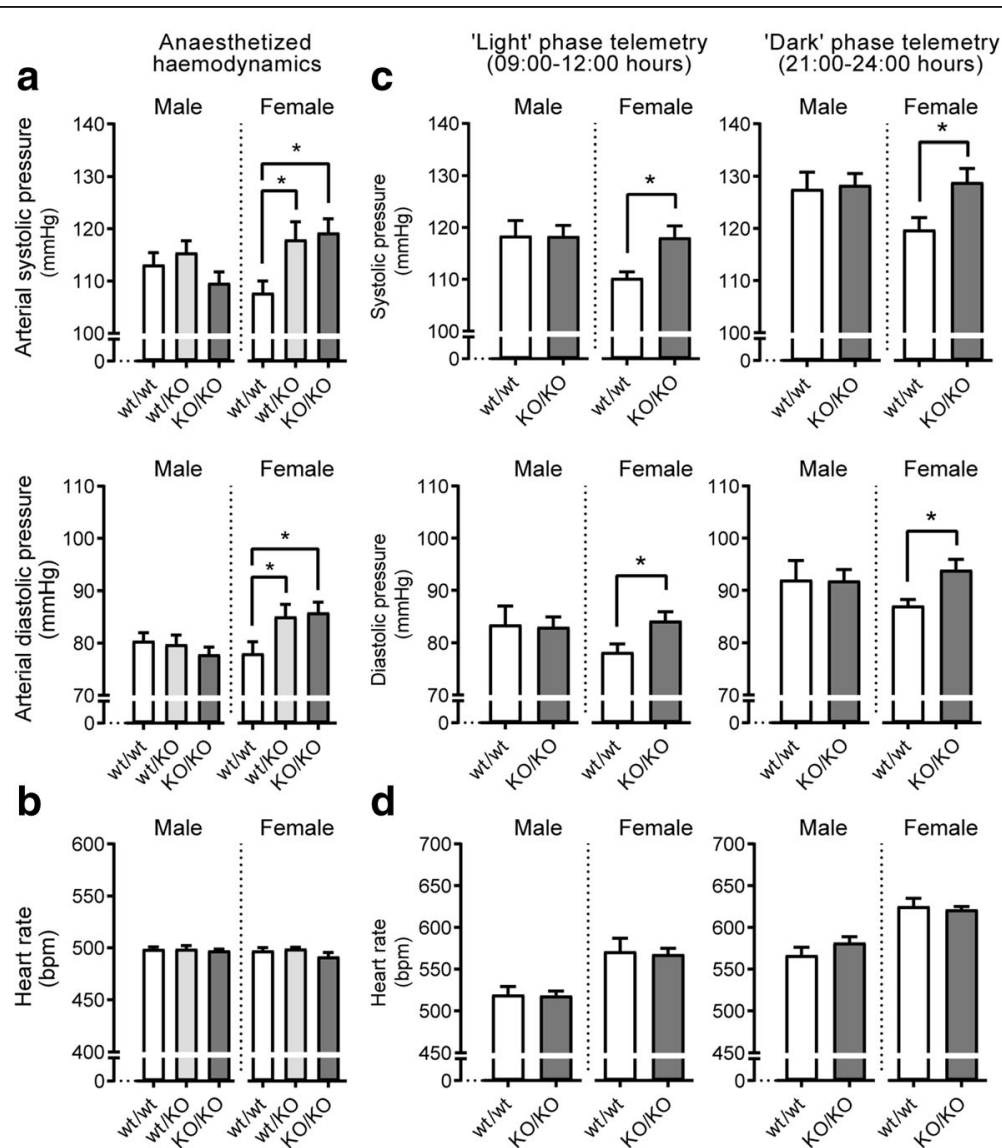

Fig. 2 Female GPR37L1 knockout mice have elevated blood pressure. a Micromanometry under anesthesia was performed on male and female mice (10-12 weeks old, $n \geq 13$, one-way ANOVA with Dunnett's post hoc test, or Kruskal-Wallis with Dunn's multiple comparisons where ANOVA assumptions were violated. $\left.{ }^{*} p \leq 0.05\right)$. $\mathbf{b}$ Heart rate did not differ between genotypes during recordings. $\mathbf{c}$ Conscious radiotelemetry in male and female mice. Data represents averaged recordings during light and dark phases of diurnal cycle over 9 days (14-16 weeks old, $n=5,{ }^{*} p \leq 0.05$, two-tailed Student's $t$ test between genotypes within each sex). $\mathbf{d}$ Heart rate did not differ between genotypes during conscious recordings 
Table 1 Hemodynamic assessment of Angll-treated (2 mg/kg/day) female GPR37L $1^{\text {wt } / w t}$ and GPR37L $1^{\mathrm{KO} / \mathrm{KO}}$ mice by micromanometry under anesthesia

\begin{tabular}{|c|c|c|c|c|c|c|c|}
\hline & \multirow{3}{*}{$\begin{array}{l}\text { Genotype } \\
\text { Treatment }\end{array}$} & \multicolumn{6}{|l|}{ Female } \\
\hline & & \multicolumn{3}{|l|}{ wt/wt } & \multicolumn{3}{|l|}{$\mathrm{KO} / \mathrm{KO}$} \\
\hline & & Vehicle & Angll & $\Delta$ & Vehicle & Angll & $\Delta$ \\
\hline \multirow[t]{5}{*}{ Aorta } & HR (bpm) & $515.6 \pm 8.0$ & $512.3 \pm 7.1$ & -3.3 & $504.4 \pm 6.8$ & $503.6 \pm 3.6$ & -0.8 \\
\hline & $\mathrm{SP}(\mathrm{mmHg})$ & $109.3 \pm 3.3$ & $135.5 \pm 4.1^{*}$ & 26.2 & $119.7 \pm 6.3$ & $130.9 \pm 3.7$ & 11.2 \\
\hline & $\mathrm{DP}(\mathrm{mmHg})$ & $78.1 \pm 2.3$ & $83.7 \pm 2.5$ & 5.6 & $83.1 \pm 2.8$ & $86.8 \pm 2.4$ & 3.7 \\
\hline & MAP $(\mathrm{mmHg})$ & $88.5 \pm 2.6$ & $101 \pm 2.8^{*}$ & 12.5 & $95.3 \pm 3.9$ & $101.5 \pm 2.7$ & 6.2 \\
\hline & $\mathrm{PP}(\mathrm{mmHg})$ & $31.2 \pm 1.2$ & $51.8 \pm 3.0^{*}$ & 20.6 & $36.6 \pm 3.6$ & $44.0 \pm 2.2$ & 7.4 \\
\hline \multirow[t]{5}{*}{ LV } & $\mathrm{HR}(\mathrm{bpm})$ & $500.9 \pm 8.2$ & $500.4 \pm 2.2$ & -0.5 & $514.0 \pm 9.6$ & $508.9 \pm 4.8$ & -5.1 \\
\hline & $\mathrm{SP}(\mathrm{mmHg})$ & $106.5 \pm 3.1$ & $128.8 \pm 1.5^{*}$ & 22.3 & $112.9 \pm 4.7$ & $126.4 \pm 2.6^{*}$ & 13.5 \\
\hline & $\mathrm{EDP}(\mathrm{mmHg})$ & $6.4 \pm 0.5$ & $7.0 \pm 1.1$ & 0.6 & $5.3 \pm 0.3$ & $8.7 \pm 1.1^{*}$ & 3.4 \\
\hline & $\mathrm{dP} / \mathrm{dT} \max (\mathrm{mmHg} / \mathrm{s})$ & $9799 \pm 860.0$ & $10,998 \pm 426.2$ & 1199 & $11,343 \pm 745$ & $12,455 \pm 383.9$ & 1112 \\
\hline & $\mathrm{dP} / \mathrm{dT} \min (\mathrm{mmHg} / \mathrm{s})$ & $-9019 \pm 853.7$ & $-9253 \pm 584.0$ & -234 & $-9262 \pm 470.2$ & $-9718 \pm 330.8$ & -456 \\
\hline \multirow[t]{6}{*}{ Morphometry } & Body weight (g) & $21.2 \pm 0.3$ & $22.3 \pm 0.3$ & 1.1 & $23.3 \pm 0.5$ & $22.3 \pm 0.3$ & -1.0 \\
\hline & Tibia length (mm) & $16.1 \pm 0.1$ & $16.1 \pm 0.1$ & 0 & $16.4 \pm 0.1$ & $16.4 \pm 0.1$ & 0 \\
\hline & HW:TL (mg/mm) & $6.5 \pm 0.1$ & $8.1 \pm 0.2^{*}$ & 1.6 & $6.8 \pm 0.1$ & $8.2 \pm 0.2^{*}$ & 1.4 \\
\hline & LWW:TL (mg/mm) & $4.6 \pm 0.1$ & $6.0 \pm 0.2^{*}$ & 1.4 & $4.9 \pm 0.1$ & $6.2 \pm 0.1^{*}$ & 1.3 \\
\hline & RVW:TL (mg/mm) & $1.4 \pm 0.0$ & $1.4 \pm 0.0$ & 0 & $1.4 \pm 0.0$ & $1.4 \pm 0.0$ & 0 \\
\hline & Lung:TL (mg/mm) & $9.9 \pm 0.4$ & $9.5 \pm 0.3$ & -0.4 & $9.3 \pm 0.5$ & $9.7 \pm 0.4$ & 0.4 \\
\hline
\end{tabular}

The two-way ANOVA results are displayed in Additional file 1: Table S3. The italics and the asterisk $\left(^{*}\right)$ indicate a significant $(p \leq 0.05)$ difference between Angll and vehicle-treated cohorts, within each genotype (Tukey's multiple comparisons test). The italics and the dagger ( $\dagger$ ) indicate a significant ( $p \leq 0.05)$ difference between Angll-treated animals of different genotypes (Tukey's multiple comparisons test). Hemodynamic data, $n \geq 8$; morphometry data, $n \geq 18$

$H R$ heart rate, $S P$ systolic pressure, $D P$ diastolic pressure, MAP mean arterial pressure, $P P$ pulse pressure, $E D$ end-diastolic pressure, $H W$ heart weight, $L V W$ left ventricle weight, $T L$ tibia length, $L V$ left ventricle, $R V W$ right ventricle weight

\section{GPR37L1 protects against Angll cardiovascular stress in male mice}

Baseline cardiovascular measures were also assessed in males. GPR37L1 ${ }^{\mathrm{wt} / \mathrm{wt}}$, GPR37L $1^{\mathrm{wt} / \mathrm{KO}}$ and GPR37L1 $1^{\mathrm{KO} / \mathrm{KO}}$ males showed no differences in any hemodynamic parameter by micromanometry (Fig. 2a, Additional file 1: Table S1). BP radiotelemetry was performed on a separate cohort of conscious male GPR37L1 ${ }^{\mathrm{wt} / \mathrm{wt}}$ and GPR37L1 ${ }^{\mathrm{KO} / \mathrm{KO}}$ animals. Consistent with previous reports [25], males had higher systolic and diastolic BP than females (Fig. 2c) and lower heart rates (Fig. 2d). The expected circadian dip was seen in both sexes (Fig. 2c).

In contrast to the females, hypertension was not sustained in male mice after 7 days of AngII infusion (Table 2), as measured by pressure-transducing catheter under anesthesia, although it was clear from the various physiological endpoints that the mice received pressure overload. While AngII treatment induced LVH for males of both genotypes, the extent of this enlargement was significantly greater in GPR37L1 $1^{\mathrm{KO} / \mathrm{KO}}$ mice (Fig. 3a, Table 2). Cardiomyocyte density reflected this difference, with only GPR37L1 ${ }^{\mathrm{KO} / \mathrm{KO}} \mathrm{LV}$ sections indicating cardiomyocyte hypertrophy in response to AngII (Fig. 3b, Additional file 1: Figure S7). In concert with exacerbated LVH, male AngII- treated GPR37L1 $1^{\mathrm{KO} / \mathrm{KO}}$ mice had increased relative lung weight (Fig. 3c), indicative of pulmonary edema resulting from congestive heart failure [26-28] and suggesting that GPR37L1 ${ }^{\mathrm{KO} / \mathrm{KO}}$ males are susceptible to AngII-induced heart failure. Indeed, we observed a blunted contractile response in AngII-treated GPR37L1 ${ }^{\mathrm{KO} / \mathrm{KO}}$ males compared to GPR37L1 ${ }^{\text {wt/wt }}$ counterparts (Table 2). Consistent with our previous cohort (Fig. 2), the baseline aortic systolic pressure of male GPR37L $1^{\mathrm{KO} / \mathrm{KO}}$ did not differ from that of GPR37L $1^{\text {wt/wt }}$ controls (one-tailed Mann-Whitney test, $p>0.05$ ) (Table 2).

As for the females, GPR37L1 $1^{\mathrm{KO} / \mathrm{KO}}$ males appeared to be protected from myocardial fibrosis (Fig. 4a, c). However, the more marked hypertrophy and therefore increased tissue area in the GPR37L $1^{\mathrm{KO} / \mathrm{KO}}$ males may have obscured the extent of absolute fibrosis which was not grossly different between genotypes (Fig. 4a).

\section{Discussion}

Here, we evaluated the cardiovascular effects of GPR37L1 using a gene inactivation mouse model. We found that BP was increased only in female GPR37L1 ${ }^{\mathrm{KO} / \mathrm{KO}}$ mice, compared to GPR37L1 ${ }^{\text {wt } / w t}$ counterparts. In contrast, AngII-induced LVH was exacerbated only in male 


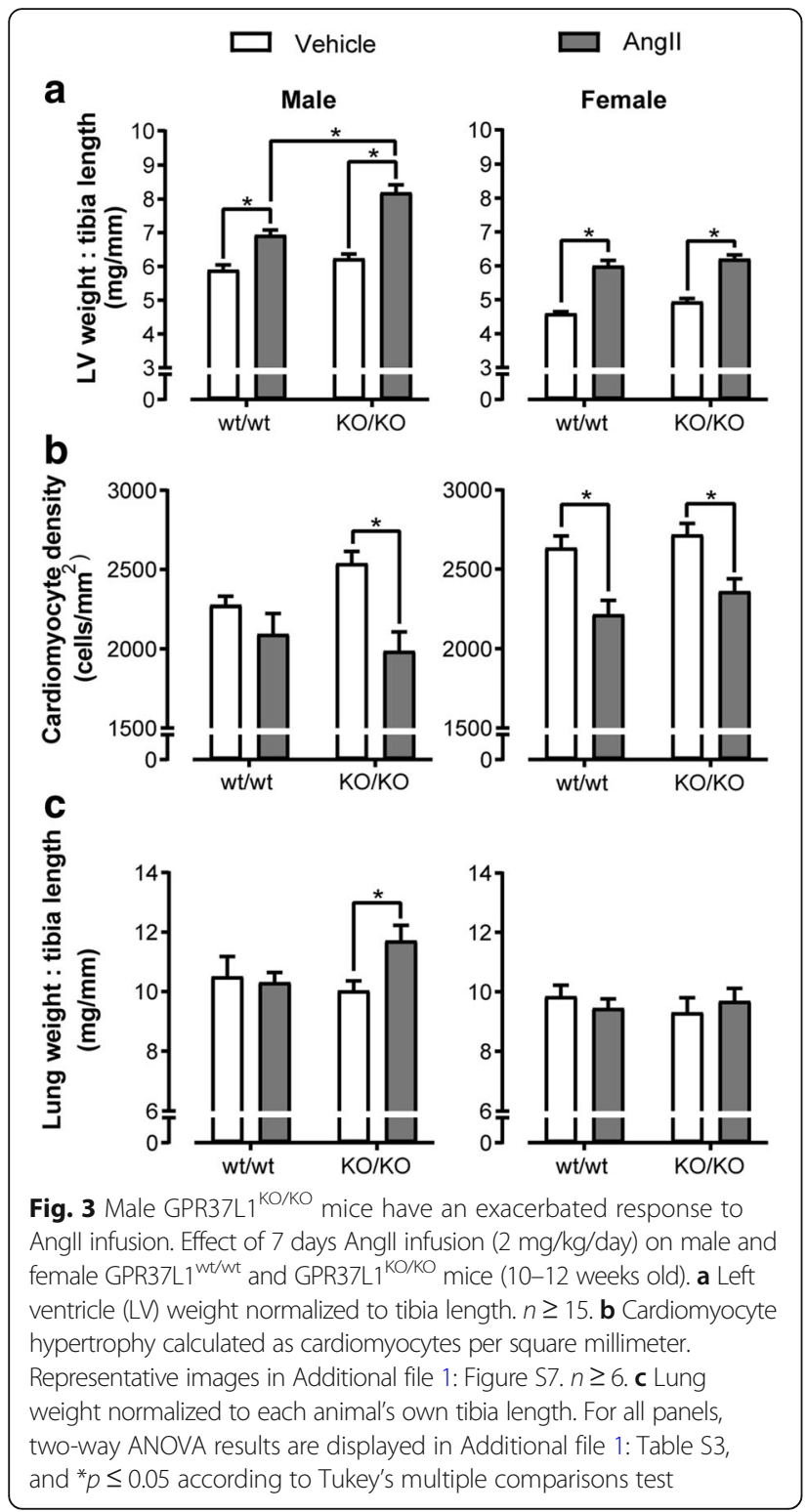

GPR37L1 $1^{\mathrm{KO} / \mathrm{KO}}$ mice and was associated with depressed contractility (reduced $\mathrm{dP} / \mathrm{dT} \max$ ) and heart failure (increased relative lung weight). Using a range of approaches, we have observed that the orphan receptor GPR37L1 is predominantly expressed in glial cells of the brain, yet we could not detect the protein in peripheral tissues. Taken together, these findings indicate GPR37L1 is an important central regulator of BP homeostasis but that its cardiovascular effects differ in males and females.

We show that female GPR37L1 $1^{\mathrm{KO} / \mathrm{KO}}$ mice had $12 \mathrm{mmHg}$ greater systolic BP than GPR37L1 $1^{\mathrm{wt} / \mathrm{wt}}$ counterparts. Such an increase in BP is not trivial, as it would translate to a doubling in cardiovascular disease risk if it were observed in humans [29]. Basal BP was unaltered in GPR37L1 ${ }^{\mathrm{KO} / \mathrm{KO}}$ males, but they failed to mount compensatory responses to AngII-induced hypertensive stress, exhibiting heightened $\mathrm{LVH}$, impaired LV contractile function, and lung congestion. The most parsimonious interpretation of our findings is that GPR37L1 $1^{\mathrm{KO} / \mathrm{KO}}$ males had an exaggerated pressor response to AngII. However, we did not observe sustained AngII hypertension in males of either genotype, despite each having obvious $\mathrm{LVH}$, and this is a potential limitation of the present study. Yet, given that $\mathrm{LVH}$ is known to increase in proportion to BP in both mouse and human hypertension [30,31], and that males are more susceptible to AngII-induced hypertension than females [32], the data suggest that AngII induced pressure overload in males of both genotypes, causing systolic dysfunction, as seen in previous rodent pressure overload studies [33]. Indeed, only males lost body weight in response to AngII, supportive of AngII being more detrimental to their health (Table 2). This broadly agrees with human heart failure epidemiology-low systolic pressure and LV function at hospital admission is more common in men [34]. Further, systolic function is better preserved in women with aortic stenosis than men, despite equivalent hypertensive stress [35]. Interestingly, GPR37L $1^{\mathrm{KO} / \mathrm{KO}}$ females appeared to be protected from cardiac fibrosis in response to AngII, despite their equivalent $\mathrm{LVH}$ and BP following infusion. The lack of detectable GPR37L1 protein in the heart suggests that, unlike the direct, pro-fibrotic effects of cardiac-expressed GPCRs (e.g., the $\beta_{2}$ adrenoceptor, $\mathrm{AT}_{1}$ and $\mathrm{ET}_{\mathrm{A}}$ receptors [36]), GPR37L1 may indirectly influence fibrosis by central modulation of circulatory factors that regulate the extracellular matrix, though this remains to be investigated. Alternatively, it is possible that the reduced cardiac fibrosis is indirectly linked to $\mathrm{LV}$ GPR37L1 transcript, rather than to protein, through regulation of miRNA, which are known to play roles in cardiac fibrosis [37]. Ultimately, detailed studies using radiotelemetry in concert with echocardiography are required to fully evaluate temporal changes in hemodynamic response to AngII, and the mechanism of decompensation in the GPR37L $1^{\mathrm{KO} / \mathrm{KO}}$ male mice, and whether GPR37L1 conveys cardioprotection in other cardiovascular disease models (i.e., thoracic aortic constriction, myocardial infarction). Such studies are currently underway.

Our observation of sexual dimorphism in the cardiovascular effects of GPR37L1 is intriguing, although sex differences in the cardiovascular control systems are known to contribute to differential disease etiology and outcomes [38, 39]. While GPR37L1 had previously been linked to hypertension [8], the animals' sex was not reported. Meanwhile, previous studies of GPR37L1 in the brain investigated only male mice $[6,40]$ or did not disclose sex [23]. Notably, sexual dimorphism has been 

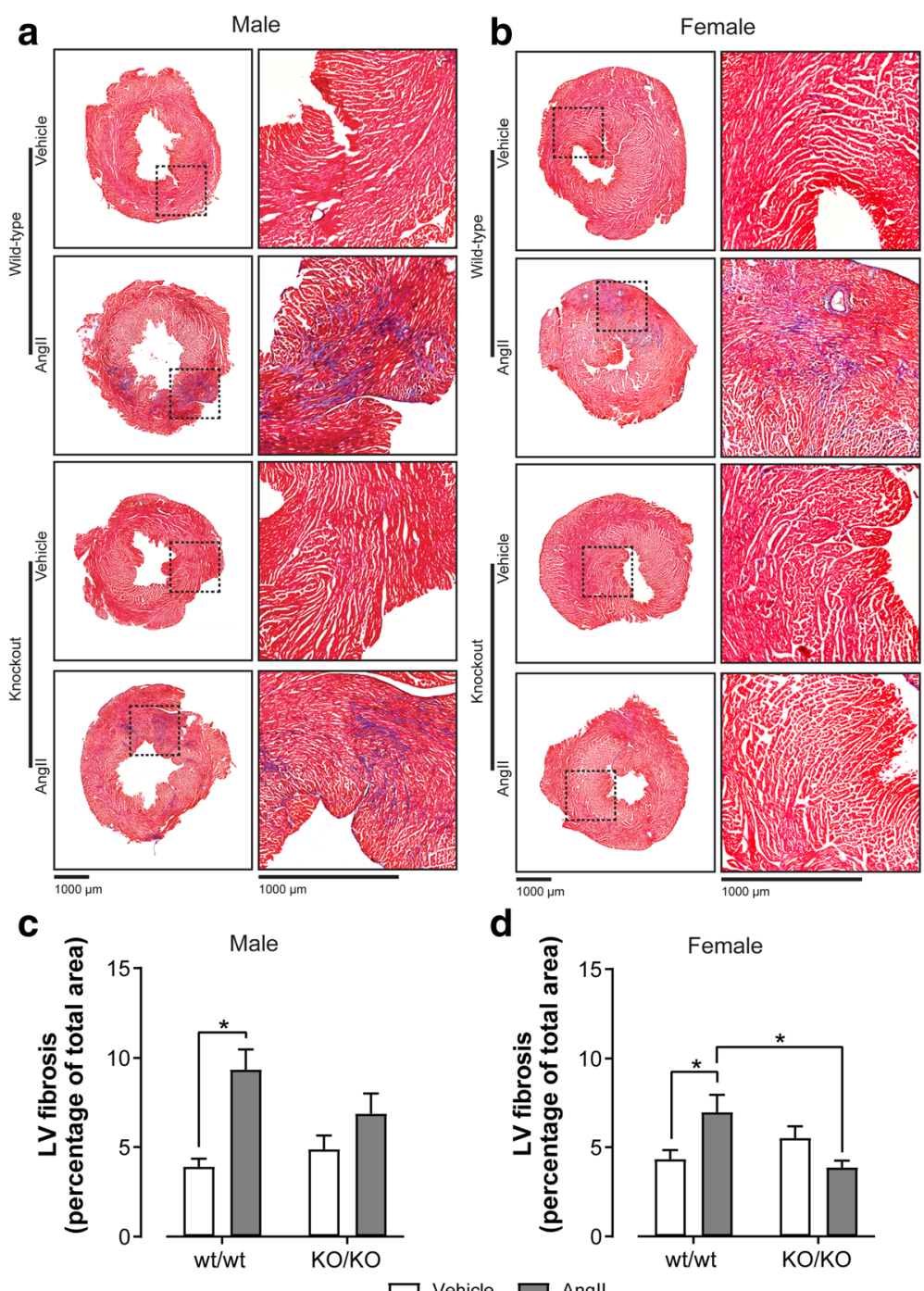

Fig. $4 \mathrm{GPR} 37 \mathrm{~L} 1^{\mathrm{KO} / \mathrm{KO}}$ mice are protected from Angll-induced cardiac fibrosis. Images of paraformaldehyde-fixed LV tissue from male (a) and female (b), vehicle- and Angll-treated GPR37L $1^{\text {wt } / w t}$ and GPR37L $1^{\mathrm{KO} / K O}$ mice were cut into 10- $\mu \mathrm{m}$ sections and stained with Masson's trichrome to highlight fibrosis (blue) and total tissue (red). Representative images of $n \geq 6$. Scale bar size as indicated on figure. Cardiac fibrosis was quantified and expressed as a percent area of total cross-sectional LV area for males (c) and females (d). $n \geq 6$, two-way ANOVA results displayed in Additional file 1: Table S3, and ${ }^{*} p \leq 0.05$ according to Tukey's multiple comparisons test

reported for GPR37, the closest phylogenetic neighbor of GPR37L1 [41], and shown to be more abundant in human females in a variety of brain sub-regions at different developmental stages [42]. Further, GPR37 deletion in mice leads to sex-dependent effects on neurotransmitter levels and anxiety [43]. In our study, we did not see significant gender differences in cerebellar GPR37L1 mRNA or protein levels (Additional file 1: Figure S9A-C). Additionally, our analysis of human postmortem brain RNA-sequencing (collected by the Genotype-Tissue Expression Consortium [21]) shows the cortex to be the only sub-region with sex differences in GPR37L1 mRNA abundance, which is increased in females (Additional file 1: Figure S9D, Table S4). Taken together, this suggests that
GPR37L1 may exert its gender-specific effects on BP via a mechanism that is independent of its expression level. Such effects might involve hormonal influences; estrogen, for example, is well known to sensitize central baroreflex and modulate sympathetic nerve activity [44].

Sex differences alone cannot reconcile the BP phenotype of GPR37L1 deletion in the present study (+ $12 \mathrm{mmHg}$, female-specific) with that previously reported (+60 $\mathrm{mmHg}$, sex not disclosed) [8]. Although both studies determined BP in anesthetized animals, our additional baseline BP measures by radiotelemetry in conscious, free-moving mice show that the $\sim 12 \mathrm{mmHg}$ increase in GPR37L1 ${ }^{\mathrm{KO} / \mathrm{KO}}$ females is independent of heart rate and anesthesia response. The magnitude of 
Table 2 Hemodynamic assessment of Angll-treated (2 mg/kg/day) male GPR37L $1^{\text {wt } / \text { wt }}$ and GPR37L ${ }^{\text {KO/KO }}$ mice by micromanometry under anesthesia

\begin{tabular}{|c|c|c|c|c|c|c|c|}
\hline & \multirow{3}{*}{$\begin{array}{l}\text { Genotype } \\
\text { Treatment }\end{array}$} & \multicolumn{6}{|l|}{ Male } \\
\hline & & \multicolumn{3}{|l|}{ wt/wt } & \multicolumn{3}{|l|}{$\mathrm{KO} / \mathrm{KO}$} \\
\hline & & Vehicle & Angll & $\Delta$ & Vehicle & Angll & $\Delta$ \\
\hline \multirow[t]{5}{*}{ Aorta } & $\mathrm{HR}(\mathrm{bpm})$ & $487.2 \pm 11$ & $498.5 \pm 13.3$ & 11.3 & $486 . \pm 7.2$ & $506.3 \pm 19.4$ & 20.3 \\
\hline & $\mathrm{SP}(\mathrm{mmHg})$ & $114 \pm 2.8$ & $127.1 \pm 6.5$ & 13.1 & $107.9 \pm 4.4$ & $118.5 \pm 6.3$ & 10.6 \\
\hline & $\mathrm{DP}(\mathrm{mmHg})$ & $78.4 \pm 1.3$ & $82.8 \pm 4.6$ & 4.4 & $75.4 \pm 3.4$ & $77.3 \pm 6.0$ & 1.9 \\
\hline & MAP (mmHg) & $90.3 \pm 1.6$ & $97.6 \pm 5.2$ & 7.3 & $86.3 \pm 3.6$ & $91.0 \pm 6.0$ & 4.7 \\
\hline & $\mathrm{PP}(\mathrm{mmHg})$ & $35.6 \pm 2.2$ & $44.3 \pm 2.7$ & 8.7 & $32.5 \pm 2.3$ & $41.2 \pm 2.6$ & 8.7 \\
\hline \multirow[t]{5}{*}{ LV } & HR (bpm) & $490.5 \pm 21.7$ & $513.6 \pm 9.4$ & 23.1 & $493.5 \pm 8.1$ & $493.5 \pm 12.1$ & 0 \\
\hline & $\mathrm{SP}(\mathrm{mmHg})$ & $113.8 \pm 4.0$ & $127.6 \pm 6.3$ & 13.8 & $109.5 \pm 2.2$ & $114.3 \pm 5.2$ & 4.8 \\
\hline & $\mathrm{EDP}(\mathrm{mmHg})$ & $7.6 \pm 1.0$ & $7.3 \pm 0.5$ & -0.3 & $5.8 \pm 0.5$ & $9.9 \pm 3.0$ & 4.1 \\
\hline & $\mathrm{dP} / \mathrm{dT} \max (\mathrm{mmHg} / \mathrm{s})$ & $10,123 \pm 953.3$ & $12,844 \pm 605.2$ & 2721 & $8772 \pm 438.1$ & $9413 \pm 733.1+$ & 641 \\
\hline & $\mathrm{dP} / \mathrm{dT} \min (\mathrm{mmHg} / \mathrm{s})$ & $-9753 \pm 1024$ & $-8684 \pm 650.6$ & 1069 & $-8517 \pm 736.7$ & $-7653 \pm 594.6$ & 864 \\
\hline \multirow[t]{6}{*}{ Morphometry } & Body weight (g) & $28.5 \pm 0.5$ & $25.7 \pm 0.4^{*}$ & -2.8 & $29.4 \pm 0.5$ & $26.5 \pm 0.3^{*}$ & -2.9 \\
\hline & Tibia length (mm) & $16.6 \pm 0.1$ & $16.6 \pm 0.1$ & 0 & $16.7 \pm 0.1$ & $16.7 \pm 0.1$ & 0 \\
\hline & $\begin{array}{l}\mathrm{HW}: \mathrm{TL} \\
(\mathrm{mg} / \mathrm{mm})\end{array}$ & $8.3 \pm 0.2$ & $9.3 \pm 0.2^{*}$ & 1.0 & $8.6 \pm 0.2$ & $10.9 \pm 0.4^{*} \dagger$ & 2.3 \\
\hline & $\begin{array}{l}\text { LWW:TL } \\
(\mathrm{mg} / \mathrm{mm})\end{array}$ & $5.9 \pm 0.2$ & $6.9 \pm 0.5^{*}$ & 1.0 & $6.2 \pm 0.1$ & $8.2 \pm 0.2^{*}+$ & 2.0 \\
\hline & $\begin{array}{l}\text { RVW:TL } \\
(\mathrm{mg} / \mathrm{mm})\end{array}$ & $1.7 \pm 0.1$ & $1.6 \pm 0.1$ & -0.1 & $1.8 \pm 0.0$ & $1.7 \pm 0.1$ & -0.1 \\
\hline & $\begin{array}{l}\text { Lung:TL } \\
\text { (mg/mm) }\end{array}$ & $10.5 \pm 0.7$ & $10.3 \pm 0.3$ & -0.2 & $10.0 \pm 0.3$ & $11.7 \pm 0.5^{*}$ & 1.7 \\
\hline
\end{tabular}

The two-way ANOVA results are displayed in Additional file 1: Table S3. The italics and the asterisk $\left(^{*}\right)$ indicate a significant $(p \leq 0.05)$ difference between Angll and vehicle-treated cohorts, within each genotype (Tukey's multiple comparisons test). The italics and the dagger ( $\dagger$ ) indicates a significant $(p \leq 0.05)$ difference between Angll-treated animals of different genotypes (Tukey's multiple comparisons test). Hemodynamic data, $n \geq 7 ;$ morphometry data, $n \geq 15$

$H R$ heart rate, $S P$ systolic pressure, $D P$ diastolic pressure, MAP mean arterial pressure, $P P$ pulse pressure, $E D P$ end-diastolic pressure, $H W$ heart weight, $L V W$ left ventricle weight, $T L$ tibia length, $L V$ left ventricle, $R V W$ right ventricle weight

the previously reported GPR37L1 hypertensive phenotype [8] is also difficult to reconcile with the effects of deletion of other major cardiovascular regulators. For example, deletion of regulator of $\mathrm{G}$ protein signaling 2 [45], endothelial nitric oxide synthase [46], adenosine $A_{2 A}$ receptor [47], and bradykinin B2 receptor [48] reportedly increased BP by $45,28,25$, and $20 \mathrm{mmHg}$, respectively. Therefore, it is likely that the effect of GPR37L1 on BP was overestimated due to the lack of comparisons to wild-type controls. Moreover, we obtained the same reported GPR37L1 knockout mouse line [8] (reanimated from frozen sperm by Charles River Laboratories, Japan) and failed to detect a change in BP by tail cuff plethysmography in a small cohort, suggesting that any BP difference in these mice is also likely to be modest (data not shown). We additionally found these mice to be of mixed genetic background. Such confounding genetic issues were avoided in our study by the use of EUCOMM conditional-ready mice [9, $10]$, enabling comparison of wild-type and null mice on the same C57BL/6J background.
How then might GPR37L1 regulate cardiovascular function? While our laboratory has shown GPR37L1 to constitutively couple to the $\mathrm{G \alpha}_{\mathrm{s}} \mathrm{G}$ protein [15], and to share antagonists with orexin and bombesin GPCRs [49], the lack of a high-affinity ligand means pharmacological probing of its physiology is intractable at present. GPR37L1 expression in the brain is well established, while its role and presence in the periphery remains unclear [41]. For example, absence of GPR37L1 mRNA in human heart and kidney has been reported [4], while another study reported low levels of GPR37L1 mRNA in both tissues in the rat [50]. Here, we also detected GPR37L1 mRNA at very low levels in the heart and kidney but could not detect GPR37L1 protein in either. Our data agree with that of the Human Protein Atlas [51], which reports no expression of GPR37L1 protein outside the brain. While vascular function remains to be explored in GPR37L1 $1^{\mathrm{KO} / \mathrm{KO}}$ mice, we did not observe any vascular $\beta$-galactosidase immunoreactivity in the heart and kidney of GPR37L $1^{\text {lacZ/wt }}$ mice, and the RNA abundance of GPR37L1 in the human artery and aorta is comparable to that of the heart and kidney [21], where 
we could not detect receptor protein. This raises the fascinating possibility that GPR37L1 is a previously undiscovered component of the CNS-cardiovascular axis. Widely expressed in astrocytes throughout the brain/brainstem, GPR37L1 may exert cardiovascular control through its proximity to autonomic control regions such as the CVLM, RVLM, and NTS [52], where astrocytes contribute to the brain renin-angiotensin system [53, 54]. Alternatively, GPR37L1 could be involved in cerebellar circuits known to influence the cardiovascular system $[55,56]$. Indeed, the cerebellum has a long-suspected role in the modulation of baroreflexes and the development of essential hypertension $[57,58]$. More speculatively, cerebellar control of respiration [59] may exert secondary influences on BP, with a recent study implicating excessive respiratory modulation by brainstem neurons in the development of rat and human hypertension [60].

\section{Conclusions}

The present study found that deletion of the orphan GPCR, GPR37L1, causes increased systolic and diastolic blood pressure in female mice. In males, however, deletion of GPR37L1 blunted a compensatory response to AngII challenge. Although we observed low levels of GPR37L1 mRNA in the mouse heart and kidney, we could not detect GPR37L1 protein in either organ. Thus, while the mechanism by which GPR37L1 regulates BP in a sexually dimorphic manner has yet to be determined, it is likely its role in cardiovascular homeostasis is confined to its CNS actions, where the protein is abundant. Thus, the present study suggests that GPR37L1 is a contributor to CNS cardiovascular control, and the sex differences therein, and may contribute to the role of the CNS in hypertension and heart failure.

\section{Additional file}

Additional file 1: List of Supplemental Digital Content. (PDF $2673 \mathrm{~kb})$

\begin{abstract}
Abbreviations
Angll: Angiotensin II; ANP: Atrial natriuretic peptide; BNP: Brain natriuretic peptide; BP: Blood pressure; CNS: Central nervous system; CVLM: Caudal ventrolateral medulla; DAPI: 4',6-Diamidino-2-phenylindole dihydrochloride; EUCOMM: European Conditional Mouse Mutagenesis Program; GAPDH: Glyceraldehyde 3-phosphate dehydrogenase; GFAP: Glial fibrillary acidic protein; GPCR: G protein-coupled receptor; GTEx: Genotype-Tissue Expression Consortium; HPRT: Hypoxanthine guanine phosphoribosyl transferase; LV: Left ventricle; LVH: Left ventricular hypertrophy; NDS: Normal donkey serum; NTS: Nucleus of the solitary tract; PFA: Paraformaldehyde; qPCR: Quantitative polymerase chain reaction; RT: Room temperature; RVLM: Rostral ventrolateral medulla; SC: Subcutaneous; WGA: Wheat germ agglutinin; a-SkA: a-skeletal actin; $\beta 2 \mathrm{M}$ : $\beta-2$ microglobulin; $\beta-\mathrm{MHC}$ : $\beta$-myosin heavy chain
\end{abstract}

\section{Acknowledgements}

We thank the VCCRI BioCORE for their assistance with animal breeding and husbandry.

\section{Funding}

This work was supported in part by NHMRC \& NHF CJ Martin and Future Leader Fellowships (NJS), a St Vincent's Clinic Foundation grant-in-aid (NJS and RMG), NHMRC Program Grants 573732 and 1074386 (RMG), and Australian Postgraduate Scholarships to JLC, MAM, and TN. JபC is additionally supported by a Simon and Michal Wilkenfeld Scholarship. NJS thanks the Mostyn Family Foundation for philanthropic support.

\section{Availability of data and materials}

The datasets generated and analyzed during the current study are available from the corresponding author on reasonable request.

\section{Authors' contributions}

JLJC, MAM, JW, NJ, JKB, AYC, NM, ZY, CGR, and NJS performed the experiments and acquired the data. JLJC, MAM, NJ, DTH, and NJS performed the data analysis. JLJC, MAM, TN, SI, MPF, AMA, RMG, and NJS interpreted the data. JLJC and NJS wrote the manuscript, and all authors approved the final manuscript.

\section{Ethics approval}

All animal work was performed in accordance with the Australia Code for the Care and Use of Animals for Scientific Purposes, 8th Edition (2013), and was approved by the relevant Animal Ethics Committees (Garvan Institute for Medical Research/St Vincent's Hospital, project number AEC 13/30; University of Melbourne, project number 1212573).

\section{Competing interests}

The authors declare that they have no competing interests.

\section{Publisher's Note}

Springer Nature remains neutral with regard to jurisdictional claims in published maps and institutional affiliations.

\section{Author details}

${ }^{1}$ Molecular Pharmacology Laboratory, Division of Molecular Cardiology and Biophysics, Victor Chang Cardiac Research Institute, Darlinghurst, NSW 2010, Australia. ${ }^{2}$ St Vincent's Clinical School, University of New South Wales,

Sydney, Australia. ${ }^{3}$ Cardiac Biology Laboratory, Victor Chang Cardiac Research Institute, Darlinghurst, NSW, Australia. ${ }^{4}$ Cardiac Physiology \& Transplantation, Victor Chang Cardiac Research Institute, Darlinghurst, NSW, Australia. ${ }^{5}$ Department of Physiology, University of Melbourne, Melbourne, Australia. ${ }^{6}$ Florey Institute of Neuroscience and Mental Health, University of Melbourne, Melbourne, Australia. ${ }^{7}$ Molecular, Structural and Computational Biology Division, Victor Chang Cardiac Research Institute, Darlinghurst, NSW, Australia.

${ }^{8}$ Cardiac Research Laboratory, University of Sydney, Camperdown, Australia.

Received: 4 December 2017 Accepted: 27 March 2018

Published online: 06 April 2018

References

1. WHO. A global brief on hypertension: silent killer, global public health crisis. 2013

2. Coffman TM. Under pressure: the search for the essential mechanisms of hypertension. Nat Med. 2011;17(11):1402-9.

3. Rimoldi SF, Messerli FH, Bangalore S, Scherrer U. Resistant hypertension: what the cardiologist needs to know. Eur Heart J. 2015;36(40):2686-95.

4. Valdenaire $O$, Giller T, Breu V, Ardati A, Schweizer A, Richards JG. A new family of orphan $\mathrm{G}$ protein-coupled receptors predominantly expressed in the brain. FEBS Lett. 1998:424(3):193-6.

5. Zeng Z, Su K, Kyaw H, Li Y. A novel endothelin receptor type-B-like gene enriched in the brain. Biochem Biophys Res Commun. 1997;233(2):559-67.

6. Marazziti D, Di Pietro C, Golini E, Mandillo S, La Sala G, Matteoni R, et al. Precocious cerebellum development and improved motor functions in mice lacking the astrocyte cilium-, patched 1-associated Gpr3711 receptor. Proc Natl Acad Sci U S A. 2013;110(41):16486-91.

7. Kent WJ, Sugnet CW, Furey TS, Roskin KM, Pringle TH, Zahler AM, et al. The human genome browser at UCSC. Genome Res. 2002;12(6):996-1006.

8. Min KD, Asakura M, Liao Y, Nakamaru K, Okazaki H, Takahashi T, et al. Identification of genes related to heart failure using global gene expression profiling of human failing myocardium. Biochem Biophys Res Commun. 2010;393(1):55-60 
9. Skarnes WC, Rosen B, West AP, Koutsourakis M, Bushell W, lyer V, et al. A conditional knockout resource for the genome-wide study of mouse gene function. Nature. 2011;474(7351):337-42.

10. Coleman JL, Brennan K, Ngo T, Balaji P, Graham RM, Smith NJ. Rapid knockout and reporter mouse line generation and breeding colony establishment using EUCOMM conditional-ready embryonic stem cells: a case study. Front Endocrinol. 2015;6:105.

11. Livak KJ, Schmittgen TD. Analysis of relative gene expression data using real-time quantitative PCR and the 2(-Delta Delta C(T)) method. Methods. 2001;25(4):402-8.

12. Soetanto R, Hynes CJ, Patel HR, Humphreys DT, Evers M, Duan G, et al. Role of miRNAs and alternative mRNA 3'-end cleavage and polyadenylation of their mRNA targets in cardiomyocyte hypertrophy. Biochim Biophys Acta. 2016;1859(5):744-56

13. Chen D, Bassi JK, Walther T, Thomas WG, Allen AM. Expression of angiotensin type $1 \mathrm{~A}$ receptors in $\mathrm{C} 1$ neurons restores the sympathoexcitation to angiotensin in the rostral ventrolateral medulla of angiotensin type 1A knockout mice. Hypertension. 2010;56(1):143-50.

14. Ono M, Murakami T, Kudo A, Isshiki M, Sawada H, Segawa A. Quantitative comparison of anti-fading mounting media for confocal laser scanning microscopy. The journal of histochemistry and cytochemistry : official journal of the Histochemistry Society. 2001;49(3):305-12.

15. Coleman JL, Ngo T, Schmidt J, Mrad N, Liew CK, Jones NM, et al. Metalloprotease cleavage of the $\mathrm{N}$ terminus of the orphan $\mathrm{G}$ protein-coupled receptor GPR37L1 reduces its constitutive activity. Sci Signal. 2016;9(423):ra36.

16. Smith NJ, Ward RJ, Stoddart LA, Hudson BD, Kostenis E, Ulven T, et al. Extracellular loop 2 of the free fatty acid receptor 2 mediates allosterism of a phenylacetamide ago-allosteric modulator. Mol Pharmacol. 2011;80(1):163-73.

17. Pacher P, Nagayama T, Mukhopadhyay P, Batkai S, Kass DA. Measurement of cardiac function using pressure-volume conductance catheter technique in mice and rats. Nat Protoc. 2008;3(9):1422-34.

18. Li M, Naqvi N, Yahiro E, Liu K, Powell PC, Bradley WE, et al. c-kit is required for cardiomyocyte terminal differentiation. Circ Res. 2008;102(6):677-85.

19. Butz GM, Davisson RL. Long-term telemetric measurement of cardiovascular parameters in awake mice: a physiological genomics tool. Physiol Genomics. 2001;5(2):89-97.

20. Tejada T, Tan L, Torres RA, Calvert JW, Lambert JP, Zaidi M, et al. IGF-1 degradation by mouse mast cell protease 4 promotes cell death and adverse cardiac remodeling days after a myocardial infarction. Proc Natl Acad Sci U S A. 2016;113(25):6949-54.

21. Consortium GT. Human genomics. The Genotype-Tissue Expression (GTEx) pilot analysis: multitissue gene regulation in humans. Science. 2015; 348(6235):648-60.

22. Robinson MD, McCarthy DJ, Smyth GK. edgeR: a bioconductor package for differential expression analysis of digital gene expression data. Bioinformatics. 2010;26(1):139-40.

23. Jolly S, Bazargani N, Quiroga AC, Pringle NP, Attwell D, Richardson WD, et al. $G$ protein-coupled receptor 37-like 1 modulates astrocyte glutamate transporters and neuronal NMDA receptors and is neuroprotective in ischemia. Glia. 2017;

24. Reddy AS, O'Brien D, Pisat N, Weichselbaum CT, Sakers K, Lisci M, et al. A comprehensive analysis of cell type-specific nuclear RNA from neurons and glia of the brain. Biol Psychiatry. 2017;81(3):252-64.

25. Barsha G, Denton KM, Mirabito Colafella KM. Sex- and age-related differences in arterial pressure and albuminuria in mice. Biol Sex Differ. 2016;7:57.

26. Liao Y, Takashima S, Maeda N, Ouchi N, Komamura K, Shimomura I, et al. Exacerbation of heart failure in adiponectin-deficient mice due to impaired regulation of AMPK and glucose metabolism. Cardiovasc Res. 2005;67(4):705-13.

27. Adachi Y, Saito Y, Kishimoto I, Harada M, Kuwahara K, Takahashi N, et al. Angiotensin II type 2 receptor deficiency exacerbates heart failure and reduces survival after acute myocardial infarction in mice. Circulation. 2003; 107(19):2406-8.

28. Kuroda J, Ago T, Matsushima S, Zhai P, Schneider MD, Sadoshima J. NADPH oxidase 4 (Nox4) is a major source of oxidative stress in the failing heart. Proc Natl Acad Sci U S A. 2010;107(35):15565-70.

29. Jones DW, Hall JE. Seventh report of the Joint National Committee on prevention, detection, evaluation, and treatment of high blood pressure and evidence from new hypertension trials. Hypertension. 2004;43(1):1-3.

30. Crowley SD, Gurley SB, Herrera MJ, Ruiz P, Griffiths R, Kumar AP, et al. Angiotensin II causes hypertension and cardiac hypertrophy through its receptors in the kidney. Proc Natl Acad Sci U S A. 2006;103(47):17985-90.
31. Rowlands DB, Ireland MA, Glover DR, McLeay RA, Stallard TJ, Littler WA. The relationship between ambulatory blood pressure and echocardiographically assessed left ventricular hypertrophy. Clin Sci. 1981;61 Suppl 7:101s-3s.

32. Xue B, Pamidimukkala J, Hay M. Sex differences in the development of angiotensin II-induced hypertension in conscious mice. Am J Phys Heart Circ Phys. 2005;288(5):H2177-84.

33. Norton GR, Woodiwiss AJ, Gaasch WH, Mela T, Chung ES, Aurigemma GP, et al. Heart failure in pressure overload hypertrophy. The relative roles of ventricular remodeling and myocardial dysfunction. J Am Coll Cardiol. 2002;39(4):664-71.

34. Gheorghiade M, Abraham WT, Albert NM, Greenberg BH, O'Connor CM, She L, et al. Systolic blood pressure at admission, clinical characteristics, and outcomes in patients hospitalized with acute heart failure. JAMA. 2006;296(18):2217-26.

35. Villari B, Campbell SE, Schneider J, Vassalli G, Chiariello M, Hess OM. Sexdependent differences in left ventricular function and structure in chronic pressure overload. Eur Heart J. 1995:16(10):1410-9.

36. Travers JG, Kamal FA, Robbins J, Yutzey KE, Blaxall BC. Cardiac fibrosis: the fibroblast awakens. Circ Res. 2016;118(6):1021-40.

37. Small EM, Olson EN. Pervasive roles of microRNAs in cardiovascular biology. Nature. 2011;469(7330):336-42.

38. Fermin DR, Barac A, Lee S, Polster SP, Hannenhalli S, Bergemann TL, et al. Sex and age dimorphism of myocardial gene expression in nonischemic human heart failure. Circ Cardiovasc Genet. 2008;1(2):117-25.

39. Mouat MA, Coleman JLJ, Smith NJ. GPCRs in context: sexual dimorphism in the cardiovascular system. Brit J Pharmacol. 2018; In Press

40. Meyer RC, Giddens MM, Schaefer SA, Hall RA. GPR37 and GPR37L1 are receptors for the neuroprotective and glioprotective factors prosaptide and prosaposin. Proc Natl Acad Sci U S A. 2013;110(23):9529-34.

41. Smith NJ. Drug discovery opportunities at the endothelin B receptor-related orphan G protein-coupled receptors, GPR37 and GPR37L1. Front Pharmacol. 2015:6:275.

42. Shi L, Zhang Z, Su B. Sex biased gene expression profiling of human brains at major developmental stages. Sci Rep. 2016;6:21181.

43. Mandillo S, Golini E, Marazziti D, Di Pietro C, Matteoni R, Tocchini-Valentin GP. Mice lacking the Parkinson's related GPR37/PAEL receptor show nonmotor behavioral phenotypes: age and gender effect. Genes Brain Behav. 2013:12(4):465-77.

44. Saleh MC, Connell BJ, Saleh TM. Autonomic and cardiovascular reflex responses to central estrogen injection in ovariectomized female rats. Brain Res. 2000;879(1-2):105-14.

45. Heximer SP, Knutsen RH, Sun X, Kaltenbronn KM, Rhee MH, Peng $\mathrm{N}$, et al. Hypertension and prolonged vasoconstrictor signaling in RGS2-deficient mice. J Clin Invest. 2003;111(8):1259.

46. Godecke A, Decking UK, Ding Z, Hirchenhain J, Bidmon HJ, Godecke S, et al. Coronary hemodynamics in endothelial NO synthase knockout mice. Circ Res. 1998;82(2):186-94.

47. Ledent C, Vaugeois JM, Schiffmann SN, Pedrazzini T, El Yacoubi M, Vanderhaeghen JJ, et al. Aggressiveness, hypoalgesia and high blood pressure in mice lacking the adenosine A2a receptor. Nature. 1997;388(6643):674-8.

48. Madeddu P, Milia AF, Salis MB, Gaspa L, Gross W, Lippoldt A, et al. Renovascular hypertension in bradykinin B2-receptor knockout mice. Hypertension. 1998;32(3):503-9.

49. Ngo T, llatovskiy AV, Stewart AG, Coleman JL, McRobb FM, Riek RP, et al Orphan receptor ligand discovery by pickpocketing pharmacological neighbors. Nat Chem Biol. 2017;13(2):235-42.

50. Leng N, Gu G, Simerly RB, Spindel ER. Molecular cloning and characterization of two putative $\mathrm{G}$ protein-coupled receptors which are highly expressed in the central nervous system. Brain Res Mol Brain Res. 1999;69(1):73-83.

51. Uhlen M, Fagerberg L, Hallstrom BM, Lindskog C, Oksvold P, Mardinoglu A, et al. Proteomics. Tissue-based map of the human proteome. Science. 2015;347(6220):1260419.

52. Guyenet PG. The sympathetic control of blood pressure. Nat Rev Neurosci. 2006;7(5):335-46.

53. O'Callaghan EL, Bassi JK, Porrello ER, Delbridge LM, Thomas WG, Allen AM. Regulation of angiotensinogen by angiotensin II in mouse primary astrocyte cultures. J Neurochem. 2011;119(1):18-26.

54. Stornetta RL, Hawelu-Johnson CL, Guyenet PG, Lynch KR. Astrocytes synthesize angiotensinogen in brain. Science. 1988;242(4884):1444-6.

55. Bradley DJ, Pascoe JP, Paton JF, Spyer KM. Cardiovascular and respiratory responses evoked from the posterior cerebellar cortex and fastigial nucleus in the cat. J Physiol. 1987;393:107-21. 
56. Bradley DJ, Ghelarducci B, Paton JF, Spyer KM. The cardiovascular responses elicited from the posterior cerebellar cortex in the anaesthetized and decerebrate rabbit. J Physiol. 1987;383:537-50.

57. Korner PI. The central nervous system and physiological mechanisms of "optimal" cardiovascular control. The Australian journal of experimental biology and medical science. 1971:49(4):319-43.

58. Korner PI. The phenotypic patterns of essential hypertension are the key to identifying "high blood pressure" genes. Physiol Res. 2010;59(6):841-57.

59. Xu F, Frazier DT. Role of the cerebellar deep nuclei in respiratory modulation. Cerebellum. 2002;1 (1):35-40.

60. Menuet C, Le S, Dempsey B, Connelly AA, Kamar JL, Jancovski N, et al. Excessive respiratory modulation of blood pressure triggers hypertension. Cell Metab. 2017;25(3):739-48.

Submit your next manuscript to BioMed Central and we will help you at every step:

- We accept pre-submission inquiries

- Our selector tool helps you to find the most relevant journal

- We provide round the clock customer support

- Convenient online submission

- Thorough peer review

- Inclusion in PubMed and all major indexing services

- Maximum visibility for your research

Submit your manuscript at www.biomedcentral.com/submit
Biomed Central 